\title{
Characterization and use efficiency of sparingly soluble fertilizer of boron and zinc for foliar application in coffee plants
}

\author{
Luiza Oliveira Macedo ${ }^{1, *}$ (D), Dirceu Mattos-Jr' (iD, Rodrigo Candido Jacobassi ${ }^{1}$ (D), Guilherme \\ Petená $^{1}$ (D), José Antonio Quaggio² (D), Rodrigo Marcelli Boaretto ${ }^{1}$ (D) \\ 1. Instituto Agronômico de Campinas - Centro de Citricultura Sylvio Moreira - Cordeirópolis (São Paulo), Brazil. \\ 2. Instituto Agronômico de Campinas-Centro de Solos e Recursos Ambientais - Campinas (São Paulo), Brazil. \\ Received: Jul. 14, 2020 | Accepted: Feb. 19, 2021 \\ Section Editor: Gabriel Constantino Blain \\ *Corresponding author: luizaoliveiram@hotmail.com \\ How to cite: Macedo, L. O., Mattos-Jr, D., Jacobassi, R. C., Petená, G., Quaggio, J. A. and Boaretto, R. M. (2021). Characterization and \\ use efficiency of sparingly soluble fertilizer of boron and zinc for foliar application in coffee plants. Bragantia, 80, e3421. https://doi. \\ org/10.1590/1678-4499.20200329
}

\begin{abstract}
Deficiencies of boron and zinc occur in coffee plantations despite the many fertilizer sources offered by the industry for the agriculture. Sparingly soluble fertilizers (SSF) have been used in several countries for many years. However, their effectiveness when applied to leaves is highly contested, and information about their use efficiency is still lacking. Experiments were set up to characterize the SSF of $\mathrm{B}$ and $\mathrm{Zn}$ according to particle size of fertilizers, and the spreading and retention of the particles in the leaf, comparing SSF (calcium borate, $\mathrm{Zn}$ oxide, and $\mathrm{Zn}$ borate) with soluble sources (boric acid and $\mathrm{Zn}$ sulfate) in four doses (mg. $\mathrm{L}^{-1}$ ): Experiment I (B 0, 130, 260, and 520), Experiment II (Zn 0, 200, 600, and 1,800), and experiment III (B 0, 43, 129, and 387, and Zn 0, 200, 600, and 1,800), to supply B and Zn for coffee plants. Microparticles of the SSF were found adhered to coffee leaves, and the Zn oxide was the one with the smallest particle size. SSFs were effective at increasing the $\mathrm{Zn}$ and $\mathrm{B}$ leaf concentrations in coffee. Dry matter of coffee increased $15 \%$ with applications of $270 \mathrm{mg} \cdot \mathrm{L}^{-1}$ of $\mathrm{B}$ as calcium borate and $384 \mathrm{mg} \cdot \mathrm{L}^{-1}$ of $\mathrm{B}$ as boric acid. Foliar application of $\mathrm{Zn}$ oxide at the dose of $1,800 \mathrm{mg} \cdot \mathrm{L}^{-1}$ of $\mathrm{Zn}$ increased the leaf areas of the plants. High doses of $Z n$ sulfate caused toxicity to coffee plants due to high saline concentrations. The microparticles found retained on the surface of the coffee leaves increased leaf concentration of $B$ and $Z n$, which explained variations in the dry matter measurements and show the potential of the SSF for the development of fertilizers to improve the availability of micronutrients to coffee.
\end{abstract}

Key words: micronutrients, microparticles, nutrient sources, leaf spraying.

\section{INTRODUCTION}

There is a large supply of micronutrient fertilizers manufactured in the world, even though nutritional disorders associated with micronutrient fertilization remain problematic for many crops of agronomic interest (Bell and Dell 2008). Therefore, studies must be developed to improve the application of micronutrients in production systems. In Brazil, boron (B) and zinc (Zn) are micronutrients that most limit the increment of coffee production (Guimarães and Reis 2010), and their deficiency is associated with low mobility in the plant and high soil adsorption for $\mathrm{Zn}$ with low soil levels for B. Foliar application has been an effective and preferential method for coffee growers to supply micronutrients, due to the ease of distribution of small quantities and by the possibility of application along with defensives (Fernández et al. 2013).

The sources most used for foliar applications in coffee are highly soluble, such as sulfates, chlorides, and nitrates. However, these fertilizer sources still offer challenges regarding application technology, such as the limited amount to be applied in the leaves to avoid phytotoxicity due to high saline indices (Kah et al. 2018), the interaction that may occur with other products in the spray tank mix (Fernández et al. 2013), and the necessity to perform new applications with each new shoot, since these micronutrients have low mobility in the phloem (Lacerda et al. 2018; Leite et al. 2007). 
In this scenario, the development of concentrated suspensions, based on micronutrients in Sparingly soluble fertilizers (SSF), such as oxides and carbonates, is the most significant technological advance that has resulted in a wide range of products optimized for growers (Bell and Dell 2008; Macedo et al. 2017; Macedo et al. 2021). To improve the efficiency of micronutrients in SSF, they have been used as micro or nanoparticles, since sources of low solubility with smaller particle sizes may favor the absorption of nutrients by plants due to greater contact surfaces (Du et al. 2015). During the use of SSF, the particles are adhered to the leaf surface and can serve as a solid phase to prolong the supply of micronutrients to the plant (Wang and Nguyen 2018). In contrast, the foliar application of soluble sources generally results in high uptake of the micronutrient by the leaves at first, but soon there is decrease in the rate of absorption (Rossi et al. 2019; Macedo et al. 2021).

A better understanding of the use efficiency of the SSF is necessary, especially for foliar applications, since in the Brazilian legislation sources registered for foliar fertilization must present completely water-solubility, which does not allow the registration and commercialization of these products for foliar use. Based on this, this study aimed to characterize fertilizer sources testing the hypothesis that physical and chemical characteristics of SSF interfere with availability of nutrients to plants, even though when in microparticles they are efficient to supply B and $\mathrm{Zn}$ to coffee plants, compared with soluble fertilizers usually recommended for coffee production. The results will promote information that supports changes in the Brazilian regulation for fertilizer registration and also can contribute to the decision making of growers in foliar source choices for coffee plantations.

\section{MATERIAL AND METHODS}

\section{Determination of the particle size of fertilizers}

The granulometric distributions of the SSFs were characterized by a particle size analyzer via laser diffraction (Mastersizer model 3,000, Malvern Instruments, Malvern, England). The studied fertilizers, calcium borate $\left[\mathrm{CaB}_{3} \mathrm{O}_{4}(\mathrm{OH})_{3} \cdot \mathrm{H}_{2} \mathrm{O}\right], \mathrm{Zn}$ oxide $(\mathrm{ZnO})$, and $\mathrm{Zn}$ borate $\left(2 \mathrm{ZnO} \cdot 3 \mathrm{~B}_{2} \mathrm{O}_{3} \cdot 3,5 \mathrm{H}_{2} \mathrm{O}\right)$, were diluted to a concentration of $100 \mathrm{mg} \cdot \mathrm{L}^{-1}$ and added to the equipment until the reading detection (Shu et al. 2007). The final particle dispersion was the average of five subsequent readings. The particle size was given in micrometers within three classes of distribution: 90,50 , and $10 \%$ of the particles found in the suspension.

\section{Contact angle}

The contact angle of a spray droplet with a hydrophobic surface was compared between SSF and soluble sources using a tensiometer Dataphysics model OCA-15EC (DataPhysics Instruments GmbH, Filderstadt, Germany), and the data was processed in the program SCA20 (DataPhysics Instruments $\mathrm{GmbH}$, Filderstadt, Germany). The droplet used was obtained from solutions prepared to contain $260 \mathrm{mg} \cdot \mathrm{L}^{-1}$ of $\mathrm{B}$ with the sources boric acid $\left(\mathrm{H}_{3} \mathrm{BO}_{3}\right)$ and calcium borate $\left[\mathrm{CaB}_{3} \mathrm{O}_{4}(\mathrm{OH})_{3} \cdot \mathrm{H}_{2} \mathrm{O}\right], 600 \mathrm{mg} \cdot \mathrm{L}^{-1}$ of $\mathrm{Zn}$ with the sources sulfate of $\mathrm{Zn}\left(\mathrm{ZnSO}_{4}\right)$ and $\mathrm{Zn}$ oxide $(\mathrm{ZnO})$, and $129 \mathrm{mg} \cdot \mathrm{L}^{-1}$ of B $+600 \mathrm{mg} \cdot \mathrm{L}^{-1}$ of $\mathrm{Zn}$ with the sources boric acid $\left(\mathrm{H}_{3} \mathrm{BO}_{3}\right)+$ zinc sulfate $\left(\mathrm{ZnSO}_{4}\right)$ and $\mathrm{Zn}$ borate $\left(2 \mathrm{ZnO} \cdot 3 \mathrm{~B}_{2} \mathrm{O}_{3} \cdot 3,5 \mathrm{H}_{2} \mathrm{O}\right)$. These doses are considered adequate for foliar spraying in coffee.

\section{Characterization of the sources of zinc and boron retained on the surface of the coffee leaf}

For the characterization of the fertilizer particles retained on the surface of the coffee leaves, a study was carried out in a greenhouse with 12-month-old coffee plants of Catuaí Amarelo [Coffea arabica (L.)]. Different plants were sprayed with solutions containing $260 \mathrm{mg} \cdot \mathrm{L}^{-1}$ of $\mathrm{B}$ with the sources boric acid $\left(\mathrm{H}_{3} \mathrm{BO}_{3}\right)$ or calcium borate $\left[\mathrm{CaB}_{3} \mathrm{O}_{4}(\mathrm{OH}) 3 \cdot \mathrm{H}_{2} \mathrm{O}\right]$ and $600 \mathrm{mg} \cdot \mathrm{L}^{-1}$ of $\mathrm{Zn}$ with the sources $\mathrm{Zn}$ sulfate $\left(\mathrm{ZnSO}_{4}\right)$ or $\mathrm{Zn}$ oxide $(\mathrm{ZnO})$, and a non-sprayed plant was also used as a control treatment. The leaves chosen to be sprayed were cleaned with distilled water before the application of treatments.

Three days after the application of treatments, three mature leaves of each plant were collected and stored on ice for preparation in the laboratory. Samples of the leaf tissue with approximately $0.5 \times 0.5 \mathrm{~cm}$ area were collected and fixed in 
Karnovsky's solution (modified from Karnovsky 1965), remaining in a vacuum pump for $5 \mathrm{~min}$, and stored in the refrigerator for at least $72 \mathrm{~h}$. The fixed samples were dehydrated in a series of acetone concentrations [30, 50, 70, 90, and 100\% (three times)], remaining $20 \mathrm{~min}$ at each step. Soon after, they were dried to the critical point using $\mathrm{CO}_{2}$, glued in stubs and metalized with gold. The leaf surface of the sampled coffee plants was then analyzed by scanning electron microscopy LEO model 435 VP (Leica, Cambridge, England), obtaining images stored in digital files of type TIFF.

\section{Supply of sparingly soluble fertilizers compared to soluble sources for coffee plants}

Three experiments were carried out in a greenhouse. One-year-old coffee plants cv. Catuaí Amarelo [Coffea arabica (L.)] were transplanted to 12-L plastic pots, filled with a substrate composed of pine bark and vermiculite. Macro and micronutrients were applied via a nutrient solution modified according to Hippler et al. (2015). The supply of macronutrients took place over 40 applications, from transplantation up to 180 days after starting treatments, and micronutrients were supplied with 15 applications during the same period according to the subsequently described experimental characteristics.

In each experiment, the treatments consisted of the application of two fertilizer sources, one soluble in water, and another sparingly soluble in water, as well as four doses of the micronutrient in a $2 \times 4$ factorial design within a completely randomized design replicated four times. Experiment I (B) consisted of foliar application of four doses of B: control (without B), 130, 260, and $520 \mathrm{mg} \cdot \mathrm{L}^{-1}$ (summing up 0, 13, 28, and $55 \mathrm{mg}^{\mathrm{p}}$ plant ${ }^{-1}$ of total $\mathrm{B}$ after 180 days), either as boric acid $\left(\mathrm{H}_{3} \mathrm{BO}_{3}\right)$ or calcium borate $\left[\mathrm{CaB}_{3} \mathrm{O}_{4}(\mathrm{OH})_{3} \cdot \mathrm{H}_{2} \mathrm{O}\right]$. Experiment $\mathrm{II}(\mathrm{Zn})$ consisted of foliar application of four doses of $\mathrm{Zn}$ : control (without $\mathrm{Zn}$ ), 200, 600 and 1,800 $\mathrm{mg}^{-\mathrm{L}^{-1}}$ (summing up 0, 23, 65, and $200 \mathrm{mg} \cdot \mathrm{plant}^{-1}$ of total $\mathrm{Zn}$ after 180 days), either as $\mathrm{Zn}$ sulfate $\left(\mathrm{ZnSO}_{4} \cdot 7 \mathrm{H}_{2} \mathrm{O}\right)$ or $\mathrm{Zn}$ oxide $(\mathrm{ZnO})$. Experiment III ( $\mathrm{B}$ and $\left.\mathrm{Zn}\right)$ consisted of foliar application of four

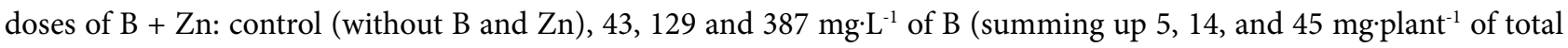
$B$ after 180 days), and corresponding to 200, 600 and 1,800 $\mathrm{mg}^{-\mathrm{L}^{-1}}$ (summing up 23, 65, and $200 \mathrm{mg} \cdot \mathrm{plant}^{-1}$ of total Zn), either as $\mathrm{H}_{3} \mathrm{BO}_{3}+\mathrm{ZnSO}_{4}$ and $\mathrm{Zn}$ borate $\left(2 \mathrm{ZnO} \cdot 3 \mathrm{~B}_{2} \mathrm{O}_{3} \cdot 3 \cdot 5 \mathrm{H}_{2} \mathrm{O}\right)$.

All SSFs utilized were characterized as microparticulates and contained flowable technology adjuvants for retention of the microparticles in leaves. An adjuvant featuring $200 \mathrm{~g} \cdot \mathrm{L}^{-1}$ of nonylphenoxy poly(ethyleneoxy)ethanol was mixed at $0.1 \mathrm{~mL} \cdot \mathrm{L}^{-1}$ to treatment solution of the soluble sources. Doses of nutrients in each experiment were defined based on the adequate concentration levels recommended for coffee by Guimarães and Reis (2010), with two additional doses in each experiment. For B (experiment I), a half and double of the adequate level; similarly, for $\mathrm{Zn}$ (experiment II), a third and triple the adequate level; and for B and $\mathrm{Zn}$ (experiment III), a third and triple of the adequate level of $\mathrm{Zn}$ and doses of B were adjusted based on the adequate dose of $\mathrm{Zn}$.

Three applications of treatments were carried out: when each coffee tree had five pairs of plagiotropic branches, 190 days after transplant, and the other two at 60 -day intervals. At the moment of foliar spraying, a plastic cover was placed on the surface of pots to avoid contamination of the substrate with sprayed solutions. The amounts of solution applied were approximately $25 \mathrm{~mL}$ per plant in the first application, $45 \mathrm{~mL}$ per plant in the second application, and $50 \mathrm{~mL}$ per plant in the third application. These values were proportional to the leaf area (LA) of plants at every period, guaranteeing a uniform coverage of the leaf surface with the sprayed solution. To adapt to the humidity conditions of the greenhouse air and simulate dew conditions, a nebulization system was activated three times per day for $30 \mathrm{~s}$, and the amount of nebulized water was not enough to allow runoff on the leaf surface.

\section{Dry matter production and chemical analysis of plant material}

Plants were destructively harvested 60 days after the last foliar application in experiments I (B), II (Zn), and III (B and $\mathrm{Zn}$ ), and separated into leaves and woody parts (stem + branches). After collection, the harvested plant material was washed with 5\% diluted detergent and distilled water (Alva and Tucker 1997) and oven-dried at $65^{\circ} \mathrm{C}$ until constant weight for quantification of the dry matter (DM). Leaves and woody parts were ground in a Wiley-type mill for determination of plant nutrient concentrations by chemical analysis according to Bataglia et al. (1983). 


\section{Statistical analysis}

Data collected were submitted to analysis of variance, and means were analyzed statistically by the F test $(\mathrm{p}<0.05)$ using Sisvar (Variance Analysis System, version 5.3, Lavras, Brazil). Regression equations were estimated for the parameters that were significant by the $\mathrm{F}$ test for dose or interaction between source and dose $(\mathrm{p}<0.05)$.

\section{RESULTS AND DISCUSSION}

Of the SSFs available for use in agriculture, $\mathrm{Zn}$ oxide is the most common in the manufacture of fertilizers (Montalvo et al. 2016). In the present work, it was identified that, among the SSFs studied, Zn oxide was the one with the smallest particle size, 90\%, with a diameter smaller than $2.04 \mu \mathrm{m}$ (Fig. 1). This smaller particle size justifies the higher Zn concentration provided by this source for coffee plants when compared with the supply of B by calcium borate ( $90 \%$ of particles $\leq 14.3 \mu \mathrm{m})$, and $\mathrm{Zn}$ and B by $\mathrm{Zn}$ borate $(90 \%$ of the particles $\leq 18.3 \mu \mathrm{m})$ (Fig. 1). The concentration of $\mathrm{Zn}$ in the leaves with the highest dose of $\mathrm{Zn}$ oxide was $230 \mathrm{mg} \cdot \mathrm{kg}^{-1}$, whereas with the same concentration in a foliar application when using the $\mathrm{Zn}$ borate source the leaf concentration was $178 \mathrm{mg} \cdot \mathrm{kg}^{-1}$ (Fig. 2). This supports the need of small particles in the suspension fertilizer for the greater efficiency of the SSF in the supply of nutrients for the plants, since the increase of the contact surface facilitates the solubilization of the microparticles and gradually provides the micronutrient to the leaves (Wang and Nguyen 2018; Rossi et al. 2019). The SSF used in this work were classified as microparticulates. To be considered nanoparticles, the materials must have particles smaller than $100 \mathrm{~nm}$ in at least one dimension (Wiesner et al. 2006), which was not found in the foliar fertilizers studied.

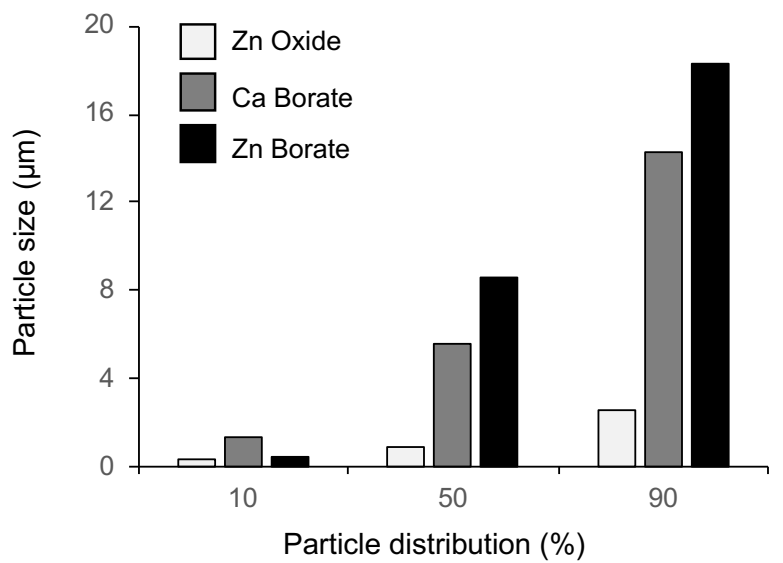

Figure 1. Distribution of particle size of sparingly soluble fertilizers of $B$ and $\mathrm{Zn}$ with suspended particles*.

*Standard deviation of mean for sources within classes up to $10 \%<0.013,0.015$, and $0.001 \mu \mathrm{m}$, up to $50 \%<0.003,0.01$, and $0.03 \mu \mathrm{m}$, and up to $90 \%<0.05$, 0.02 , and $0.03 \mu \mathrm{m}$, respectively within the classes, for the sources $\mathrm{Zn}$ oxide, $\mathrm{Ca}$ borate, and $\mathrm{Zn}$ borate.

In addition to particle size, other important features for the efficiency of SSFs are the adhesion and scattering of the droplets on the leaf surface, measured by the contact angle between the droplet and the hydrophobic surface of the leaf. The adhesion of the SSF in the leaf blade could be verified visually after foliar application (Figs. 3a and 3e). The suspension retained in the leaves was also confirmed by the analyses of leaves images under scanning microscopy (Figs. 4 and 5), in which microparticles were found retained on the abaxial and adaxial surface of the coffee leaves and were concentrated and fixed at the droplets fall sites of fertilizer source in leaf epidermis. When soluble sources (boric acid, and $\mathrm{Zn}$ sulfate) were used, no retained particles were found, nor were particles found on leaves that did not receive micronutrient spraying. The particles found adhered to the faces of the coffee leaves were, within the distribution, in the class of the smallest particles of the fertilizer, 1.8 to $3.5 \mu \mathrm{m}$ for calcium borate (Fig. 4) and 1.3 to $1.6 \mu \mathrm{m}$ for Zn oxide (Fig. 5), which suggests that smaller particles have greater potential for foliar retention. 

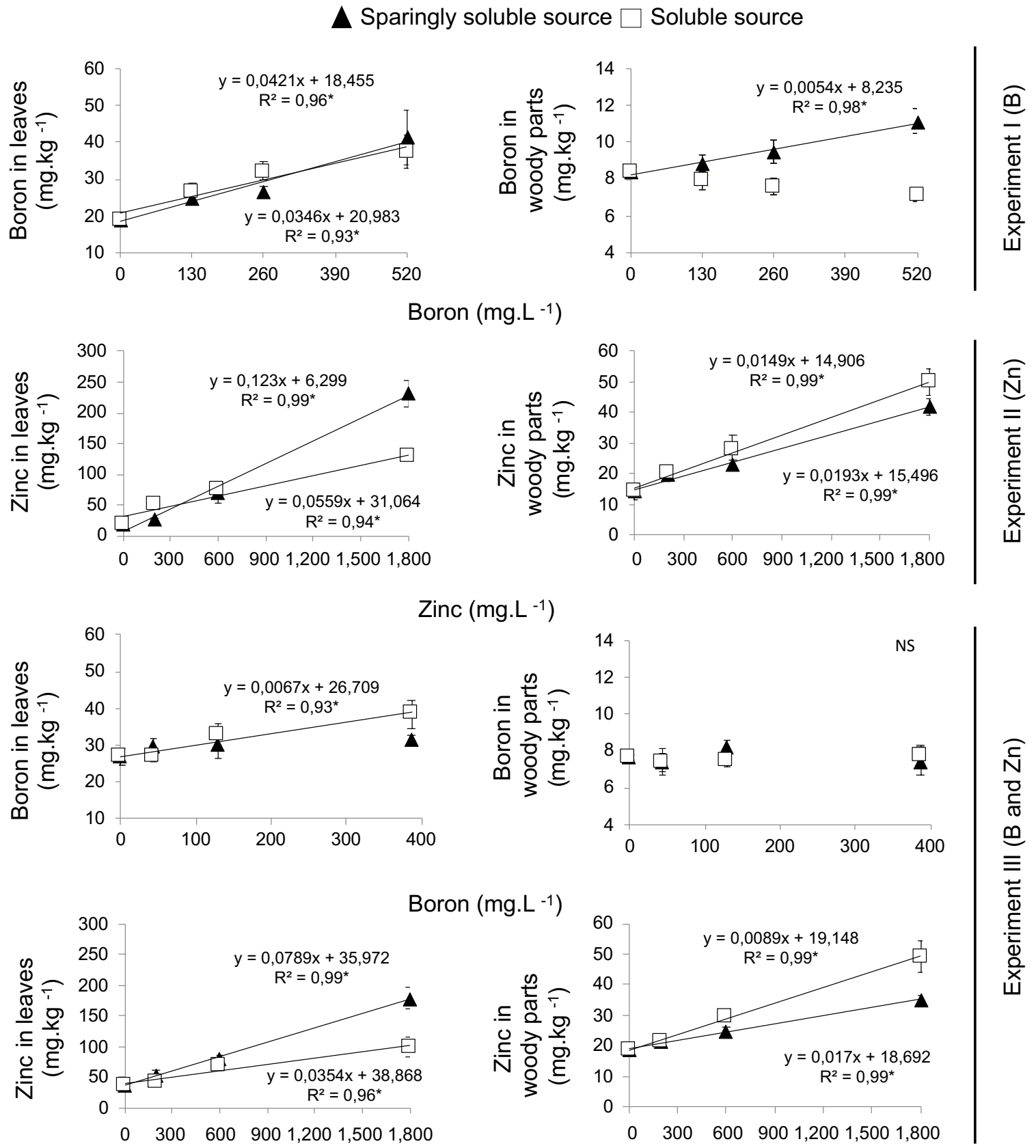

\section{Boron (mg.t $\left.{ }^{-1}\right)$}
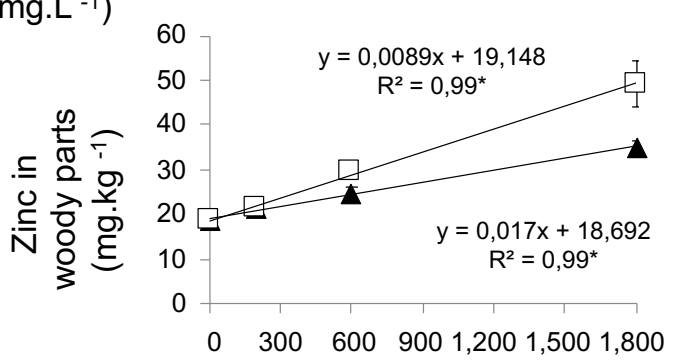

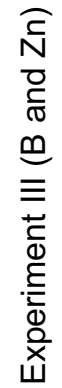

Zinc (mg.L $\left.{ }^{-1}\right)$

Figure 2. Zn and B concentrations in the leaves and woody parts of young coffee plants sprayed with soluble and sparingly soluble sources of $\mathrm{Zn}$ and $\mathrm{B}$ at increasing concentrations harvested after 60 days since the last application. Vertical lines represent the standard error of the mean $(n=4)$.

${ }^{*}$ significant at $1 \%$; ${ }^{\text {NS}}$ not significant at $5 \%$ by the $\mathrm{F}$ test.

For SSFs, the fact that the particles were retained on the leaf surface for a long period and the environmental conditions of the greenhouse, nebulized daily to simulate dew, provided a favorable condition for the gradual solubilization of these sources, that ensured the continuous supply of micronutrients to the leaves during the intervals of greatest need for the plant (Fernández and Brown 2013; Du et al. 2015). Those sources would be also less susceptible to runoff during the rainy season, when the adherent particles can continue to supply nutrients (Kraemer et al. 2009). 
Experiment II (Zn)
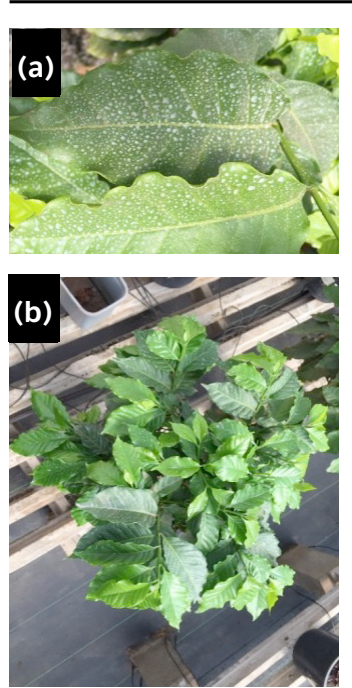
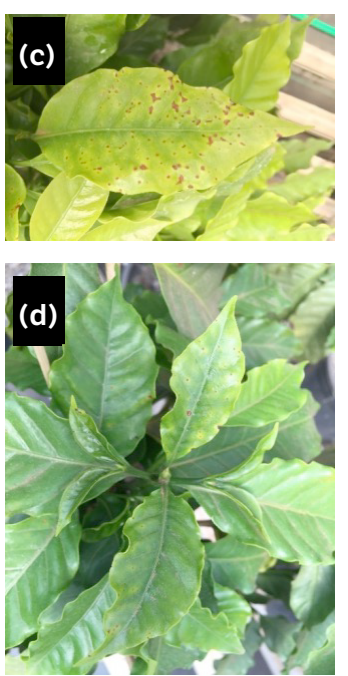

Experiment III (B e Zn)
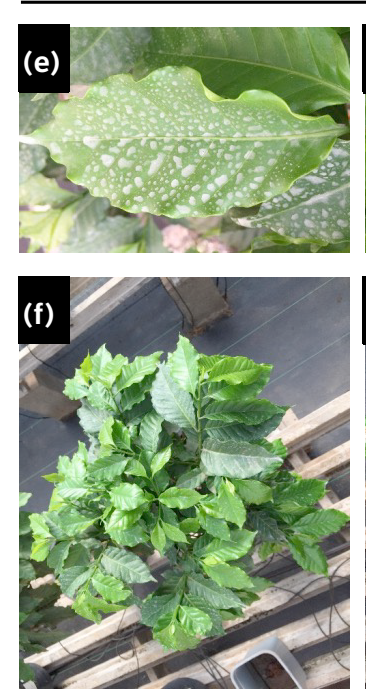

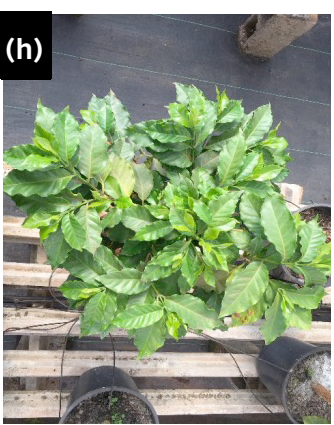

Figure 3. Young leaf of coffee applied with (a) Zn oxide, (b) upper view of young coffee plant applied with Zn oxide, (c) young leaf of coffee applied with Zn sulfate, (d) upper view of young coffee plant applied with Zn sulfate, (e) young leaf of coffee applied with Zn borate, (f) upper view of young coffee plant applied with Zn borate, $(\mathrm{g})$ young leaf of coffee applied with Zn sulfate and boric acid, (h) upper view of young coffee plant applied with Zn sulfate and boric acid.
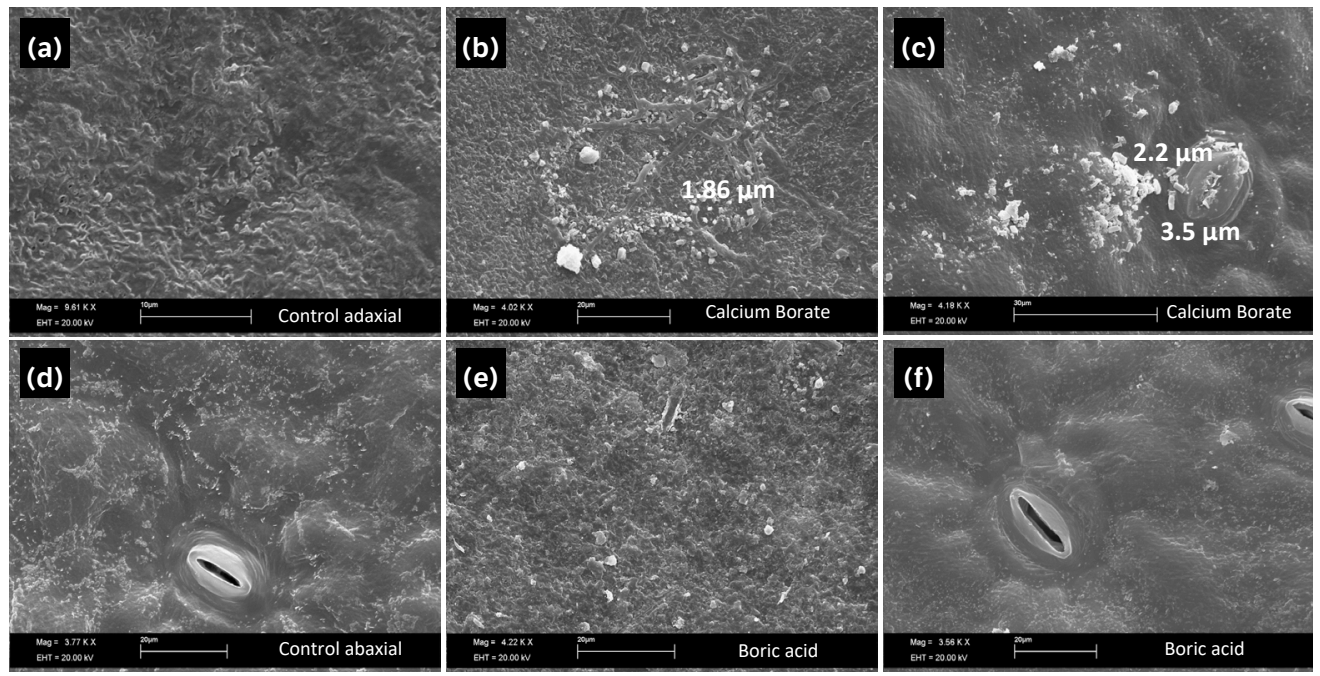

Figure 4. Scanning electron microscopy of coffee leaves sprayed with B sources and collected after three days. (a) Adaxial leaf face without spraying, (b) adaxial leaf face sprayed with B as calcium borate, (c) abaxial leaf face sprayed with B as calcium borate, (d) abaxial leaf face without spraying, (e) adaxial leaf face sprayed with B as boric acid, (f) abaxial leaf face sprayed with B as boric acid.

The spray droplet distribution is also important, since the total amount of ions absorbed by the leaves is limited by the area of the cuticle covered by the sprayed solution. Therefore, the efficacy of the SSF can potentially be improved by increasing the spray area of the leaves, which is a better strategy than increasing the concentration of micronutrients in the suspension (Du et al. 2015). In this study, an adjuvant was added in the salt formulations to equalize the adjuvants already present in the concentrated suspension of the SSF. The spreader effect was detected by the contact angle measured between the spray droplet and a hydrophobic surface using both sources, especially after the $20 \mathrm{~s}$ of the contact of the droplet with the surface (Fig. 6). The measured angle for the droplet obtained with solutions of soluble salts was lower $\left(77.5^{\circ}\right)$ than for the droplets from the suspension of SSF $\left(105^{\circ}\right)$ (Fig. 6). Despite the SSF droplets did not have a very large spreading effect, 
that fact may have contributed to a greater humectant effect with improved solubilization of the SSF microparticles, since the droplet with lower contact angle takes longer to evaporate.
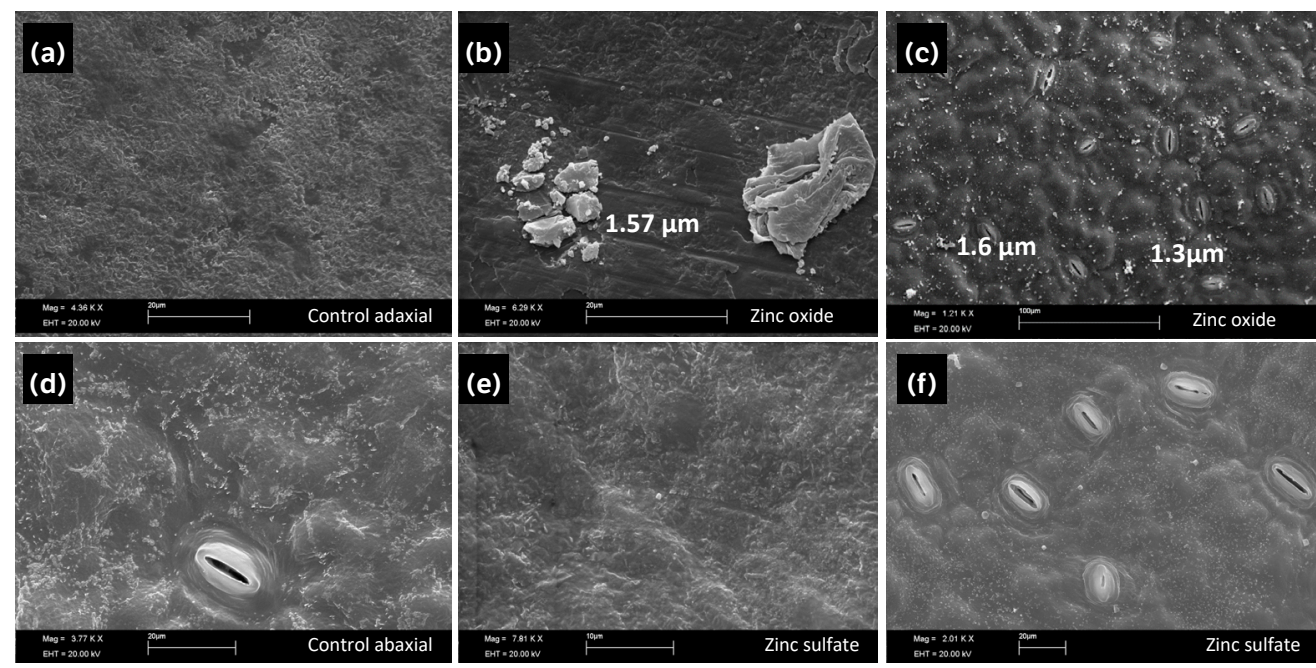

Figure 5. Scanning electron microscopy of coffee leaves sprayed with Zn sources and collected after three days. (a) Adaxial leaf face without spraying, (b) adaxial leaf face sprayed with Zn as Zn oxide, (c) abaxial leaf face sprayed with Zn as Zn oxide, (d) abaxial leaf face without spraying, (e) adaxial leaf face sprayed with $\mathrm{Zn}$ as $\mathrm{Zn}$ sulfate, ( $f$ ) abaxial leaf face sprayed with Zn as Zn sulfate.
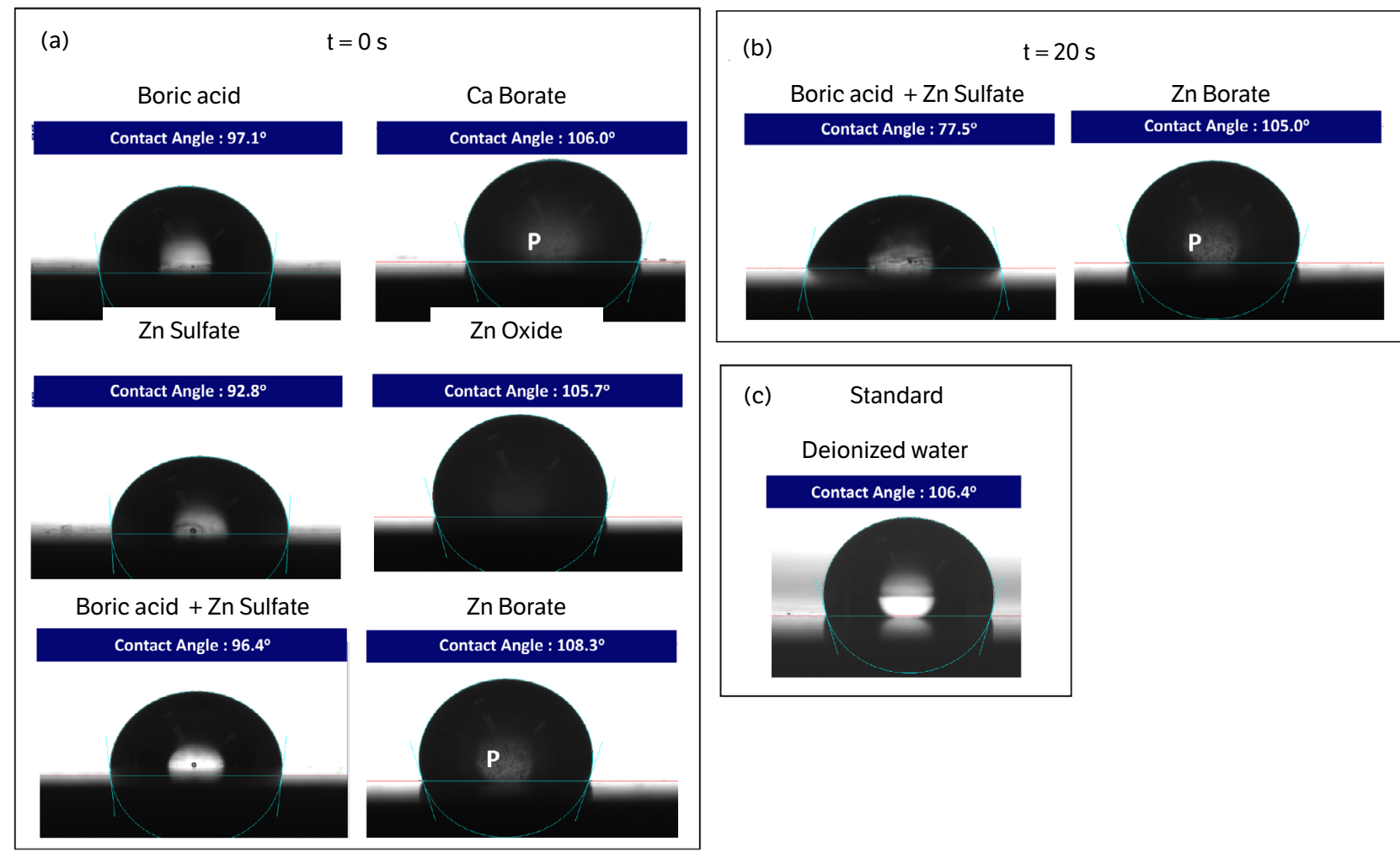

Figure 6. Angle of contact between the spray droplet and a hydrophobic surface, using soluble and sparingly soluble sources of $\mathrm{Zn}$ and $\mathrm{B}$, at (a) time $0 \mathrm{~s}(\mathrm{t}=0 \mathrm{~s})$ and at (b) time $20 \mathrm{~s}(\mathrm{t}=20 \mathrm{~s})$, and (c) in comparison with the deionized water standard.

t: time; $P$ : particles in the spray droplet from sparingly soluble sources.

The coffee leaves have a very waxy and thick cuticle that favors the flow of solutions and pulverized suspensions to the tip of the leaf. Different types of cuticular waxes have already been classified for several plants, demonstrating this 
greater waxiness for some species (Viana et al. 2018), which have differences in surface polarity and hydrophobicity of cuticles and have great influence on the effectiveness of foliar sprays (Fernández et al. 2013). It was observed soon after the foliar applications that there were solution and suspension drainages during spraying in some plants, due to the greater waxiness of the coffee cuticle, which generates greater hydrophobicity, fact that was also supported by the images of electron microscopy. The flow of suspension generated larger droplets in the leaf blade of the coffee, which sometimes accumulated on the tip of the leaf.

Considering that for the absorption of nutrients from SSF, it is ideal that greater coverage of the surface of the leaf occurs with the spray, as well as, consequently, larger contact surface of the adhered microparticle (Du et al. 2015). In some coffee plants sprayed with calcium borate in the high dose of $\mathrm{B}$, absorption was possibly impaired by the solution flow, whereas in other plants the leaf deposition was ideal and the concentration was higher than those reached with boric acid. This variability can be noted by the standard error on the plot of B concentration in the leaves in experiment I (B) (Fig. 2). Therefore, with the high dose of $\mathrm{B}$ with calcium borate, there was decrease in the aerial part DM, even with foliar $\mathrm{B}$ concentration (40 $\mathrm{mg} \cdot \mathrm{kg}^{-1}$ ), on average. Those plants that had above-adequate leaf concentration may have had reduction in DM of aerial part, collaborating with a general reduction for the treatment, when calculated on average (Fig. 7).

The B concentration for the coffee plants reached with the SSF in experiment I (B) was the same as those of the soluble source for all doses applied. The adequate dose of $\mathrm{B}\left(260 \mathrm{mg} \cdot \mathrm{L}^{-1}\right.$ of B) provided $30 \mathrm{mg} \cdot \mathrm{kg}^{-1}$, which can be considered adequate for young coffee plants when sampling leaves from the whole aerial part, not only the diagnosis leaf (Fig. 2). The highest dosage of B applied (520 mg. $\mathrm{L}^{-1}$ of B) provided $40 \mathrm{mg} \cdot \mathrm{kg}^{-1}$ of B in the leaves, which is not considered a toxic concentration for coffee yet (Leite et al. 2007) (Fig. 2).

Coffee is one of the crops that respond most to B fertilization, and its deficiency compromises processes such as sugar transport, cell wall synthesis and structure, lignification, membrane integrity, phenol metabolism and ribonucleic acid (RNA) metabolism (Rosolem and Leite 2007; Wang and Nguyen 2018), which explains the rises in leaf DM and LA up to the adequate dose of $\mathrm{B}$ for the SSF, and up the high dose for soluble source, showing that $\mathrm{B}$ is fulfilling its physiological role in the coffee plants equally for both sources (Fig. 6). In experiment III ( $\mathrm{B}$ and $\mathrm{Zn}$ ), with increasing doses of B, there was a rise of leaf concentration only for the soluble source, which as in experiment I (B) reached the concentration of $40 \mathrm{mg} \cdot \mathrm{kg}^{-1}$ at the highest dose (387 mg. $\mathrm{L}^{-1}$ ) (Fig. 2), showing that $\mathrm{Zn}$ borate was not efficient in providing B for coffee as it was for $\mathrm{Zn}$.

In experiment II ( $\mathrm{Zn})$, the $\mathrm{Zn}$ concentrations achieved with the two sources were higher than those considered adequate for coffee. Values above $30 \mathrm{mg} \cdot \mathrm{kg}^{-1}$ of $\mathrm{Zn}$ are already considered high for coffee (Guimarães and Reis 2010), and the concentration found in the leaves in the adequate $\mathrm{Zn}$ dose was $70 \mathrm{mg} \cdot \mathrm{kg}^{-1}$ of $\mathrm{Zn}$. Despite the plants reaching even higher levels of $\mathrm{Zn}\left(230 \mathrm{mg} \cdot \mathrm{kg}^{-1}\right)$ in the highest dose of $\mathrm{Zn}$ oxide (Fig. 2), there were no noticeable differences in the DM of the aerial part of the coffee trees, and the LA kept increasing (Fig. 7). A similar situation occurred in experiment III (B and $\mathrm{Zn}$ ). In the adequate dose the leaf concentrations were 70 and $80 \mathrm{mg} \cdot \mathrm{kg}^{-1}$ of $\mathrm{Zn}$, respectively for soluble and SSF, coffee trees had high $\mathrm{Zn}$ and, with the highest dose of $\mathrm{Zn}$ borate, the concentration was even higher than the adequate ( $180 \mathrm{mg} \cdot \mathrm{kg}^{-1} \mathrm{of}$ $\mathrm{Zn}$ ). In the same pattern of experiment II, even with the high levels of $\mathrm{Zn}$ observed, coffee plants continued to show DM increase up to the highest dose of $\mathrm{Zn}$ borate (Fig. 7).

Studies indicate that coffee is tolerant to high doses of $\mathrm{Zn}$, which accumulates in the branches as a mechanism of tolerance to the excess of metals in the plant (Andrade et al. 2010). This was verified for adult coffee trees, which had symptoms of $\mathrm{Zn}$ toxicity when supplied with $600 \mathrm{~g}$ of $\mathrm{Zn}$ via soil only two years after application, and the contents in the branches were larger than in the leaves already in the first year (Tezotto et al. 2012). In this work, the $\mathrm{Zn}$ concentration in woody parts was not higher than in the leaves, due to the application being foliar, but reached levels of $50 \mathrm{mg} \cdot \mathrm{kg}^{-1}$ in experiments II ( $\mathrm{Zn}$ ) and III (B and Zn), considered high (Fig. 2). This tolerance may explain the response in the LA in experiment II (Zn) and DM in experiment III ( $\mathrm{B}$ and $\mathrm{Zn}$ ), even with high $\mathrm{Zn}$ concentration achieved with the highest dose of SSF. In experiments II $(\mathrm{Zn})$ and III (B and $\mathrm{Zn}$ ), there was reduction of LA when the highest dose of $\mathrm{Zn}$ sulfate was applied (Fig. 7). This decrease seems not to have been regulated by leaf concentration since the soluble source provided a smaller concentration of $Z n$ in the leaves when compared to $\mathrm{Zn}$ oxide and $\mathrm{Zn}$ borate. Thus, the cause of toxicity to plants with a high dose of $\mathrm{Zn}$ sulfate may have been due to the high saline concentration of the spray solution prepared with a soluble source, which in contact with the leaves causes tissue damage and can reduce the LA (Fernández et al. 2013, Macedo et al. 2021). This damage can 
be verified in coffee leaves of the experiments II (Zn) and III (B and Zn), characterized by yellowish sores that evolved in the leaf limb (Figs. 3c, 3d, 3g, and 3h).

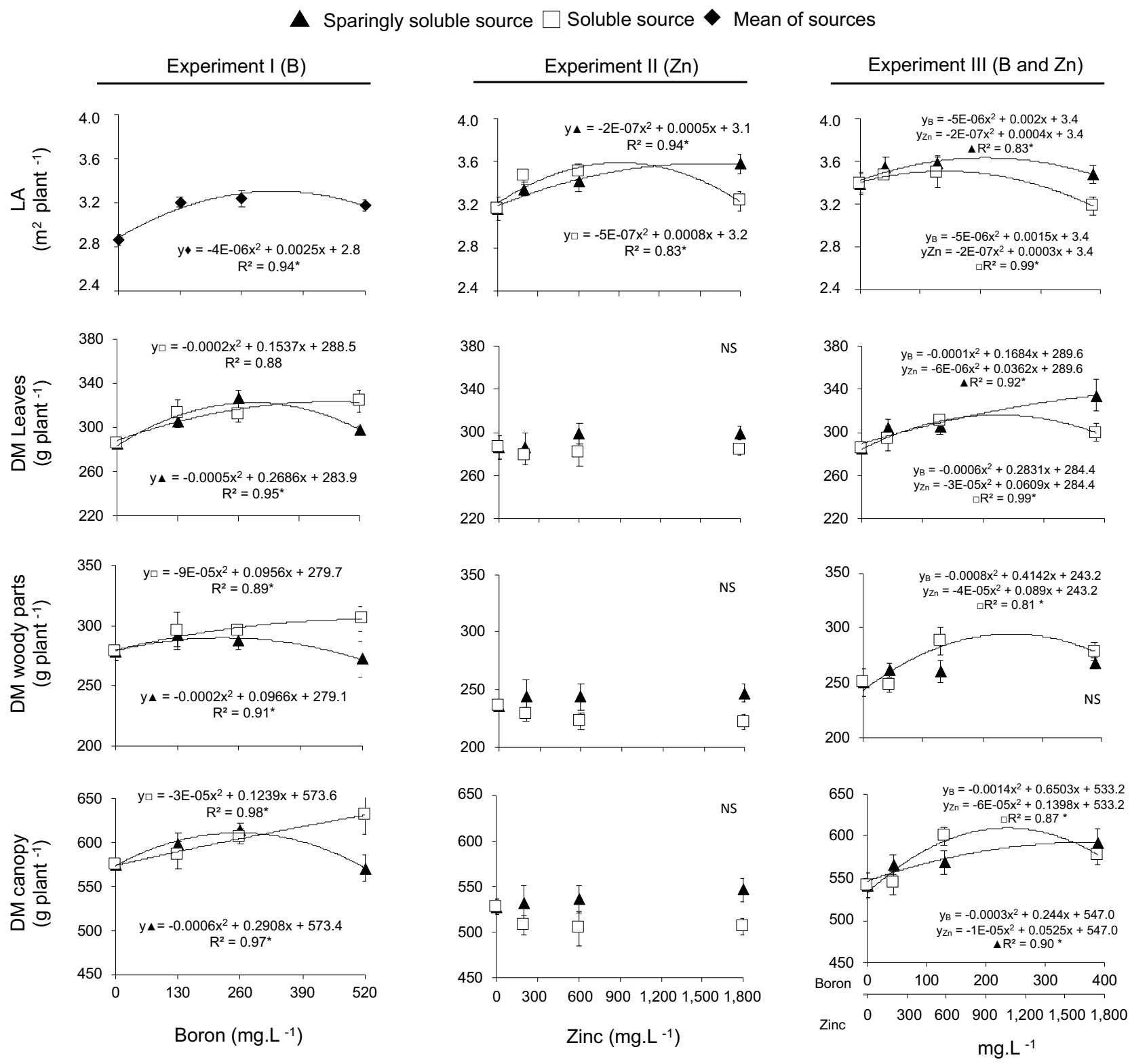

Figure 7. LA and DM of leaves, woody parts, and canopy of young coffee plants sprayed with soluble and sparingly soluble sources of Zn and $B$ at increasing concentrations harvested after 60 days since the last application. Vertical lines represent the standard error of the mean $(n=4)$.

*significant at $5 \%$; ${ }^{N}$ not significant at $5 \%$ by the $\mathrm{F}$ test; LA: leaf area; DM: dry matter.

The LA was the parameter most affected by the different sources and nutrient doses applied in young coffee plants in experiment II ( $\mathrm{Zn})$. $\mathrm{Zn}$ is involved in the metabolism of indolacetic acid (AIA), responsible for the growth of plants. Thus, nutrient deficiency causes metabolic disorders that lead to leaf size reduction, a typical symptom of Zn deficiency in coffee (Lacerda et al. 2018), which probably explains the minor LA in the control dose of experiment II (Zn), in which the concentration was very low (17 mg. $\mathrm{kg}^{-1}$ of $\mathrm{Zn}$ ). In experiment III (B and $\mathrm{Zn}$ ), the $\mathrm{Zn}$ concentration in the leaves was $36 \mathrm{mg} \cdot \mathrm{kg}^{-1}$ in the control. Therefore, with a higher $\mathrm{Zn}$ concentration in the leaves, the LA was not as impaired as it was in experiment II. 
The iron concentration in coffee leaves in experiment III ( $\mathrm{Zn}$ and B) decreased in all applied doses of nutrients for both sources, although it was even higher when the soluble sources were used (Fig. 8). Zinc may interact with different nutrients, affecting soil availability and plant absorption and, consequently, the distribution and/or use in its metabolism (Hippler et al. 2015). The reduction of Fe in the leaves and their accumulation in the root of the citrus were found because of a mechanism to detoxification or tolerance to the excess of $\mathrm{Cu}$ in the nutritive solution, since the absorption does not discriminate $\mathrm{Cu}$ and $\mathrm{Fe}$ (Hippler et al. 2016). This probable metal retention mechanism may have occurred for the coffee in the present experiment to contain the excess of $\mathrm{Zn}$.

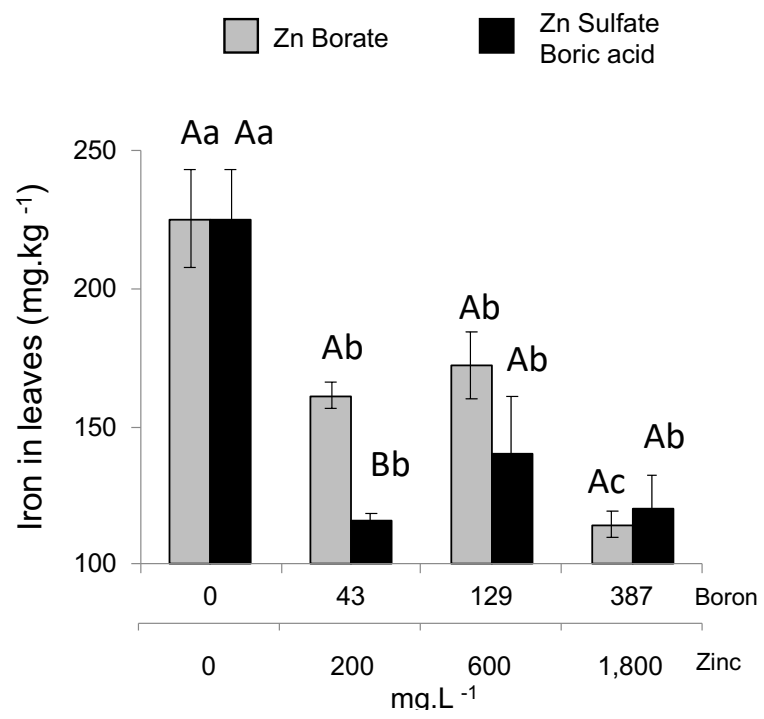

Figure 8. Iron concentration in leaves of young coffee plants sprayed with zinc borate sources (sparingly soluble) and boric acid + zinc sulfate (soluble), with increasing concentrations and harvested 60 days after the last application. Vertical lines represent the standard error of the mean $(n=4)$. Means with different lowercase letters are significant at $5 \%$ by the Tukey test between doses. Means with different capital letters are significant at $5 \%$ by the Tukey test between sources.

The characterization of SSF made in this study is an important source of information to regulate the use of these new sources, since technical specifications noticed here, such as particle size, adjuvants, and application technology, impact the supply of micronutrients by SSF. The technical specification results of the SSFs studied in this article, in addition to the correlations between micronutrient supply and coffee DM, demonstrate the potential use of these sources.

\section{CONCLUSION}

The SSFs of B and Zn were characterized as microparticles. It was concluded that fertilizers with small particles and adjuvants exhibit great capacity to be retained in the leaf blade and, consequently, were subject to solubilization by air humidity, which increased the availability of these micronutrients to the coffee trees over the time, without causing phytotoxic even at high doses. The leaf concentration of these micronutrients explained variations in the DM of leaves, woody parts, and LA, whose adequate concentration provided increases in these parameters, and corresponding decreases when in excess, demonstrating that SSF can supply the coffee plants with the micronutrients similarly to the soluble fertilizers usually recommended in the agriculture. Thereby, the results presented here show the potential for using these SSFs as foliar fertilizers for coffee trees.

\section{AUTHORS' CONTRIBUTION}

Conceptualization: Quaggio, J. A., Mattos-Jr. D. and Boaretto, R. M.; Methodology: Boaretto, R. M., Macedo, L. O. and Petená, G.; Investigation: Macedo, L. O., Jacobassi, R., Boaretto, R. M. and Petená, G.; Writing - Original Draft: Macedo, 
L. O.; Writing - Review and Editing: Mattos-Jr, D. and Boaretto, R. M.; Funding Acquisition: Boaretto, R. M.; Resources: Mattos-Jr, D.; Supervision: Boaretto, R. M.

\section{DATA AVAILABILITY STATEMENT}

All dataset were generated and analyzed in the current study.

\section{FUNDING}

Fundação de Apoio à Pesquisa Agrícola

Process No. 1039

Conselho Nacional de Desenvolvimento Científico e Tecnológico

[http://doi.org10.13039/501100003593]

Grants No: 311713/2020-3;313539/2020-0.

\section{ACKNOWLEDGMENTS}

The authors thank Nelson Horowitz and João Maças, from Yara Fertilizer, for providing the foliar sources.

\section{REFERENCES}

Alva, A. K. and Tucker, D. P. H. (1997). Surface decontamination of citrus leaves for macro and micronutrient analysis. Proceedings of the Florida State Horticultural Society, 110, 86-88.

Andrade, S. A. L., Silveira, A. P. D. and Mazzafera, P. (2010). Arbuscular mycorrhiza alters metal uptake and the physiological response of Coffea arabica seedlings to increasing Zn and Cu concentrations in soil. Science of the Total Environment, 408, 5381-5391. https:// doi.org/10.1016/j.scitotenv.2010.07.064

Bataglia, O. C., Furlani, A. M. C., Teixeira, J. P. F., Furlani, P. R. and Gallo, J. R. (1983). Methods of chemical analysis of plants. Campinas: Instituto Agronômico.

Bell, R. W. and Dell, B. (2008). Micronutrients for sustainable food, feed, fibre and bioenergy production. Paris: International Fertilizer Industry Association.

Du, Y., Li, P., Nguyen A. V., Xu, Z. P., Mulligan, D. and Huang, L. (2015). Zinc uptake and distribution in tomato plants in response to foliar supply of Zn hydroxide-nitrate nanocrystal suspension with controlled Zn solubility. Journal of Plant Nutrition and Soil Science, 178, 722731. https://doi.org/10.1002/jpln.201400213

Fernández, V. and Brown, P. H. (2013). From plant surface to plant metabolism: the uncertain fate of foliar-applied nutrients. Frontiers in Plant Science, 4, 289. https://doi.org/10.3389\%2Ffpls.2013.00289

Fernández, V., Sotiropoulos, T. and Brown, P.H. (2013). Foliar Fertilisation: Principles and Practices. Paris: International Fertilizer Industry Association. Guimarães, P. T. G. and Reis, T. H. P. (2010). Nutrição e Adubação do Cafeeiro. In P. R. Reis and R. L. Cunha (Eds.), Café Arábica do plantio à colheita (p. 343-414). Lavras: EPAMIG. 
Hippler, F. W. R., Boaretto, R. M., Quaggio, J. A., Boaretto, A. E., Abreu-Junior, C. H. and Mattos Jr., D. (2015). Uptake and distribution of soil applied zinc by citrus trees - addressing fertilizer use efficiency with 68Zn labeling. PloS One, 10, e0116903. https://doi.org/10.1371/ journal.pone.0116903

Hippler, F. W. R., Cipriano, D. O., Boaretto, R. M., Quaggio, J. A., Gaziola, S. A., Azevedo, R. A. and Mattos-Jr., D. (2016). Citrus rootstocks regulate the nutritional status and antioxidant system of trees under copper stress. Environmental and Experimental Botany, $130,42-52$. https://doi.org/10.1016/j.envexpbot.2016.05.007

Kah, M., Kookana, R. S., Gogos, A. and Bucheli, T. D. (2018). A critical evaluation of nanopesticides and nanofertilizers against their conventional analogues. Nature Nanotechnology, 13, 677-684. https://doi.org/10.1038/s41565-018-0131-1

Karnovsky, M. J. (1965). A formaldehyde-glutaraldehyde fixative of high osmolality for use in electron microscopy. Journal of Cell Biology, 27, 137-138.

Kraemer, T., Hunsche, M. and Noga, G. (2009). Selected calcium salt formulations: Interactions between spray deposit characteristics and Ca penetration with consequences for rain-induced wash-off. Journal of Plant Nutrition, 32, 1718-1730. https://doi.org/10.1080/01904160903150958

Lacerda, J. S., Martinez, H. E., Pedrosa, A. W., Clemente, J. M., Santos, R. H., Oliveira, G. L. and Jifon, J. L. (2018). Importance of zinc for arabica coffee and its effects on the chemical composition of raw grain and beverage quality. Crop Science, 58, 1360-1370. https://doi. org/10.2135/cropsci2017.06.0373

Leite, V. M., Brown, P. H. and Rosolem, C. A. (2007). Boron translocation in coffee trees. Plant and Soil, 290, 221-229. https://doi.org/10.1007/ s11104-006-9154-8

Macedo, L. O., Boaretto, R. M., Jacobassi, R., Carr, N. F., Quaggio, J. A., Mattos-Jr., D. (2017). Use of sparingly soluble micronutrients sources for citrus production. Citrus Research \& Technology, 38, 1-10. http://dx.doi.org/10.4322/crt.ICC099

Macedo, L. O., Mattos Júnior, D., Jacobassi, R., Hippler, F. W. R., Quaggio, J. A. and Boaretto, R. M. (2021). Efficiency of foliar application of sparingly soluble sources of boron and zinc in citrus. Scientia Agricola, 78, e20180387. https://doi.org/10.1590/1678-992x-2018-0387

Montalvo, D., Degryse, F., Silva, R. C., Baird, R. and McLaughlin, M. J. (2016). Chapter Five - Agronomic Effectiveness of Zinc Sources as Micronutrient Fertilizer. Advances in Agronomy, 139, 215-267.

Rosolem, C. A. and Leite, V. M. (2007). Coffee leaf and stem anatomy under boron deficiency. Revista Brasileira de Ciência do Solo, 31, 477-483. http://dx.doi.org/10.1590/S0100-06832007000300007

Rossi, L., Fedenia, L. N., Sharifan, H., Ma, X. and Lombardini, L. (2019). Effects of foliar application of zinc sulfate and zinc nanoparticles in coffee (Coffea arabica L.) plants. Plant Physiology and Biochemistry, 135, 160-166. https://doi.org/10.1016/j.plaphy.2018.12.005

Shu, X., Wu, Y. C., Cheng, J. G., Xia, Y. H. and Zheng, Y. C. (2007). Mastersizer 2000 laser particle size analyzer and its applications. Journal of Hefei University of Technology (Natural Science), 30, 164-167.

Tezotto, T., Favarin, J. L., Azevedo, R. A., Alleoni, L. R. F. and Mazzafera, P. (2012). Coffee is highly tolerant to cadmium, nickel and zinc: plant and soil nutritional status, metal distribution and bean yield. Field Crops Research, 125, 25-34. https://doi.org/10.1016/j.fcr.2011.08.012

Viana, M. T. R., Gama, T. C. P., Guedes, J. M., Guimarães, R. J., Azevedo, H. P. A., Castanheira, D. T. and Naves, V. L. (2018). Genetic divergence between coffee genotypes resistant to rust based on anatomical features. Revista de Ciências Agroveterinárias, 17,547-555. https://doi.org/10.5965/223811711732018547

Wang, S.-L. and Nguyen, A. D. (2018). Effects of Zn/B nanofertilizer on biophysical characteristics and growth of coffee seedlings in a greenhouse. Research on Chemical Intermediates, 44, 4889-4901. https://doi.org/10.1007/s11164-018-3342-z

Wiesner, M. R., Lowry, G. V., Alvarez, P., Dionysiou, D. and Biswas, P. (2006). Assessing the risks of manufactured nanomaterials. Environmental Science and Technology, 40, 4336-4345. https://doi.org/10.1021/es062726m 